\title{
PEMANFAATAN SISTEM INFORMASI GEOGRAFIS UNTUK PENYUSUNAN PETA KESESUAIAN JENIS KEMENYAN (Styrax spp.) DI SUMATERA UTARA
}

\author{
(Utilization of Geographic Information System to Develop \\ Land Suitability Map for Styrax spp. in North Sumatera) \\ Ahmad Dany Sunandar \\ Balai Penelitian Kehutanan Aek Nauli \\ Kampus Kehutanan Aek Nauli Jl. Raya Prapat Km 10,5 Sibaganding, Simalungun, 21174, Sumatera Utara \\ Telp. 0625-41659; Fax. 0625-41653 \\ email: sunandar_dany@yahoo.com
}

Naskah masuk : 1 September 2011; Naskah diterima : 22 Mei 2012

\begin{abstract}
Styrax gum is one of the potential high economic commodity in North Sumatra. This product is produced from a traditionally region which is known as styrax producer. However, there are still more widely area which can produce this product as well. Land suitability map was developed as a spatial model to show where potential area for styrax plantation extention in North Sumatra which was based on spatial data and was using geographic information system in analysing data. The result show that elevation is the most influence factor in developing land suitability of styrax. Based on validation model, there are 2,191,931 ha which are suitable for kemenyan plantation or about 30.37\% of North Sumatera Province area. The spatial model used is valid enough since it has $85.27 \%$ accuracy.
\end{abstract}

Keywords: Land suitability, North Sumatra, spatial model, styrax gum

\begin{abstract}
ABSTRAK
Kemenyan (Styrax spp.) adalah komoditas andalan Sumatera Utara yang mempunyai nilai ekonomis. Selama ini, kemenyan hanya dihasilkan dari daerah-daerah yang secara tradisional memang telah dikenal sebagai penghasil kemenyan. Sesungguhnya masih banyak daerah lain yang potensial untuk dikembangkan sebagai penghasil kemenyan, dengan demikian agar pengembangan jenis ini lebih terarah maka perlu disusun peta kesesuaian lahannya. Peta tersebut akan memberikan petunjuk daerah-daerah yang cocok untuk ditanami kemenyan. Hasil analisis menunjukkan bahwa faktor ketinggian merupakan faktor yang paling berpengaruh dalam penyusunan peta kesesuaian lahan untuk jenis kemenyan. Berdasarkan hasil validasi, luas daerah yang mempunyai tingkat kesesuaian tinggi untuk pengembangan kemenyan seluas 2.191.931 hektar atau 30,37\% dari total luas wilayah Propinsi Sumatera Utara. Model spasial yang digunakan mempunyai akurasi $85,27 \%$ sehingga dapat disimpulkan sebagai model yang valid.
\end{abstract}

\section{Kata kunci : Kesesuaian lahan, Sumatera Utara, model spasial, kemenyan}

\section{PENDAHULUAN}

Kemenyan (Styrax spp.) merupakan salah satu tanaman andalan Sumatera Utara yang cukup potensial untuk dikembangkan. Jenis ini memiliki nilai ekonomis yang tinggi sebagai bahan baku kosmetika dan bahan pengikat parfum agar keharumannya tidak cepat hilang. Kemenyan berguna pula sebagai bahan pengawet dan bahan baku farmasi/obat-obatan, juga dapat dipakai sebagai bahan campuran dalam pembuatan keramik agar lebih kuat dan tidak mudah pecah. Bahkan di negara-negara Eropa kemenyan digunakan sebagai bahan campuran pada pemanas ruangan (Anonymous, 2006). Negara-negara tujuan ekspor kemenyan saat ini antara lain India, Singapura, Hongkong dan Malaysia(Guntara, 2007).

Perkembangan budidaya kemenyan sampai saat ini belum optimal yang ditandai oleh 
tidak adanya perbaikan pola budidaya maupun pemungutan getahnya. Selain itu, penelitian inovatif yang mengarah peningkatan produktifitas tanaman kemenyan masih langka, juga berperan terhadap kurang berkembangan budidaya kemenyan dan bermuara terhadap produktifitas tanaman kemenyan yang rendah yaitu berkisar 2,7 - 3,5 ton/ha (Jayusman, 1998). Di Sumatera Utara, kemenyan merupakan komoditi spesifik yang mempunyai nilai mistik cukup lama dalam kehidupan masyarakat. Selain untuk keperluan ritual masyarakat juga sebagai bahan baku industri rokok dan parfum dengan nilai ekonomi cukup tinggi (Sasmuko, 2001). Manfaat tanaman kemenyan selain sebagai penghasil getah bernilai tinggi, juga dapat dikembangkan sebagai tanaman reboisasi, penghara pabrik pulp, rehabilitasi lahan, sekat bakar dan pohon ornamen (Pinyopusarerk, 1994, dalam Jayusman et al., 1999). Selain itu juga bisa berfungsi sebagai tanaman obat (Warintek, 2009).

Pemanfaatan Sistem Informasi Geografis (SIG) dalam evaluasi dan penyusunan peta kesesuaian lahan (land suitability) sudah sangat luas dan untuk berbagai bidang, antara lain untuk evaluasi kesesuaian lahan pertanian (Liu et al., 2006; Liu dan Deng, 2001; Kalagiroua, 2002), kesesuaian habitat flora dan fauna, perencanaan bentang alam dan perencanaan wilayah (Malczewski, 2004). Tulisan ini bertujuan untuk menyusun peta kesesuaian lahan bagi jenis kemenyan dalam rangka lebih meningkatkan keberhasilan pengembangan program penanaman kemenyan berdasarkan informasi persyaratan tempat tumbuh tanaman dan kondisi biofisik lahan yang ada di Sumatera Utara. Berdasarkan peta kesesuaian ini diharapkan pengembangan penanaman kemenyan akan lebih berhasil dan mempunyai produktivitas yang lebih baik.

\section{METODE PENELITIAN}

Untuk menyusun peta kesesuaian lahan, data pertama yang diperlukan adalah persyaratan tempat tumbuh tanaman yang bisa diperoleh dari studi literatur maupun informasi berdasarkan tempat tumbuh tegakan yang ada di alam. Data atau informasi mengenai persyaratan tempat tumbuh yang paling utama adalah mengenai kisaran elevasi, tipe iklim atau jumlah curah hujan tahunan minimal yang diperlukan, jenis tanah yang paling cocok (suitable) serta kemiringan lahan yang biasanya berkaitan dengan kedalaman tanah. Faktor-faktor pembatas inilah yang kemudian menjadi dasar dalam pengolahan data spasial yang diolah menggunakan software ArcView 3.2.

\section{A. Jenis Data yang Dikumpulkan}

Data spasial yang diperlukan adalah data yang berkaitan dengan biofisik seperti data topografi yang bisa diturunkan menjadi data ketinggian tempat serta data kemiringan serta data tipe penggunaan lahan (land use), data curah hujan, data jenis tanah serta data lain yang semakin lengkap akan semakin baik. Masingmasing data tersebut tersimpan dalam setiap lapisan (layer) dimana pengolahan data spasial ini kemudian akan berdasarkan pada pengolahan masing-masing layer tersebut.

Data spasial yang digunakan dalam penelitian ini adalah terdiri dari data sekunder berupa peta yang sudah terdigitasi dan data hipotetik yang meliputi :

\section{Peta Rupa Bumi Indonesia (RBI)}

Peta RBI yang digunakan berskala 1: 50.000 yang dikeluarkan oleh Bakosurtanal untuk wilayah Sumatera Utara tahun 1989. Data yang digunakan dari peta ini terutama data kontur (garis yang menunjukkan ketinggian tempat yang sama) yang kemudian diolah menjadi peta kemiringan (slope) dan peta ketinggian (elevasi). Dari hasil pengolahan peta kontur dihasilkan peta hasil reklasifikasi untuk kelas ketinggian/elevasi (8 kelas dengan selang $300 \mathrm{~m}$ ) dan kelas kelerengan/ slope (5 kelas).

\section{Peta Sistem Lahan (landsystem)}

Peta ini mempunyai skala 1:250.000 dan dikeluarkan oleh RePProT (Regional Planning Program for Transmigration) tahun 1987. Dari peta ini dapat diekstrak berbagai informasi yang berkaitan dengan biofisik lingkungan seperti jenis tanah, curah hujan, suhu rata-rata, jumlah bulan kering/bulan basah dan sebagainya. Informasi yang digunakan dalam penelitian ini adalah jenis tanah (klasifikasi USDA-United States Department of Agriculture), jumlah curah hujan dan kisaran suhu rata-rata tahunan.

\section{Peta sebaran pohon kemenyan}

Peta ini merupakan data spasial dimana lokasi sebaran didasarkan pada kecamatan yang banyak ditemui pohon kemenyan berdasarkan data Potensi Desa tahun 2003, 
sedangkan data jumlah pohon pada setiap lokasi merupakan data hipotetik. Data yang ada akan dibagi menjadi data untuk analisis (pembangunan model) dan data untuk validasi model yang dibangun dengan jumlah masingmasing $78 \%$ dan $22 \%$ dari jumlah titik pada peta hasil observasi dan menyebar secara merata. Peta sebaran pohon kemenyan pada setiap lokasi ini akan menjadi data observasi pada tahap pemberian skor (scoring).

\section{B. Pembangunan Data Spasial}

Pembangunan data spasial dilakukan dengan mengolah dan menyimpan data yang diperoleh ke dalam bentuk peta tematik, yaitu peta wilayah kajian (Provinsi Sumatera Utara), peta kelas ketinggian, peta kelas lereng (slope), peta curah hujan, peta jenis tanah dan peta sebaran pohon kemenyan (sebagai data hipotetik).

Peta kelas ketinggian dan peta kelas lereng dibuat dengan menurunkan dari peta kontur menggunakan software ArcView, peta curah hujan dan peta jenis tanah merupakan hasil ekstraksi dari peta RePProT dengan pengolahan data atributnya.

Metode yang digunakan dalam penyusunan peta kesesuaian lahan adalah dengan memadukan (matching) persyaratan tempat tumbuh tanaman dengan kondisi biofisik lingkungan dengan menggunakan data spasial dari sistem informasi geografis (SIG), hingga diperoleh peta kesesuaian lahan untuk setiap jenis tanaman. Metode penyusunan peta kesesuaian lahan selengkapnya dapat dilihat dalam Gambar 4.

Berdasarkan persyaratan tempat tumbuh tanaman kemnyan, maka data spasial yang ada kemudian diolah dengan melakukan overlay atau tumpang susun untuk setiap layer. Areal yang sesuai dengan persyaratan tempat tumbuh tanaman adalah areal hasil irisan dari semua layer yang di-overlay yang kemudian dikategorikan sebagai areal yang sesuai. Sebaliknya, areal yang tidak masuk dalam irisan tersebut dikategorikan sebagai areal yang tidak sesuai untuk jenis tersebut.

Persyaratan tempat

Data/Peta spasial :

tumbuh :



Gambar (Figure) 1. Alur kerja penyusunan peta kesesuaian lahan (Flowchart in developing land suitability map)

\section{Analisis Data}

Analisis spasial menggunakan Sistem Informasi Geografis (SIG) berdasarkan metode overlay (tumpang susun), pengkelasan (classify), pembobotan (weigthing) dan pengharkatan (scoring).
Komponen biofisik yang digunakan dalam analisis kesesuaian ini didasarkan pada faktor yang menentukan dalam persyaratan tumbuh tanaman kemenyan sesuai dengan literatur yaitu ketinggian/elevasi, kelas lereng/slope, curah hujan rata-rata tahunan, jenis tanah sebagai 
lapisan/layer yang akan ditumpang susunkan (overlay) dan sebagai acuan untuk validasi adalah peta sebaran pohon kemenyan.

Pemberian skoring dan pembobotan dilakukan secara empiris berdasarkan data hasil overlay antara komponen-komponen biofisik dengan data sebaran pohon kemenyan. Setiap peubah pada setiap layer dihitung luasnya untuk mengetahui sebaran kemenyan per satuan luas tertentu dan untuk mengetahui nilai harapan keberadaan ditemukannya pohon kemenyan dari proporsi luas setiap peubah dengan total luasnya. Berdasarkan nilai rasio antara observasi dengan nilai ekspektasi maka diperoleh nilai skoring untuk setiap peubah, sedangkan untuk menghitung bobotnya dihitung dengan menggunakan metode CMA (Composite Mapping Analysis) dengan menggunakan nilai rata-rata kerapatan pohon dengan nilai total kerapatannya (Mendoza dan Prabhu, 2002).

Skoring :

$$
\text { Skor }=\frac{\left[\left(\frac{O}{E}\right) / \sum \frac{O}{E}\right]-\min \frac{O}{E}}{\max \frac{O}{E}-\min \frac{O}{E}} \times 8+1
$$

Keterangan :

$\mathrm{O}=$ nilai hasil observasi

$\mathrm{E}=$ nilai ekspektasi

Min = nilai minimal

Max $=$ nilai maksimal

Nilai skor di atas akan menghasilkan kisaran nilai dari 1 hingga 9, sedangkan untuk peubah lain di tempat tidak ada pohon kemenyan yang ditemukan di dalamnya diberikan skor 0 .

Pembobotan :

Bobot $=$ (nilai rata-rata kerapatan pohon/nilai kerapatan total)

Nilai indeks kesesuaian :

$\mathrm{IK}_{\mathrm{n}}=\mathrm{S}_{\min }+$ Selang dan/atau IK $=\mathrm{Ik}_{\mathrm{n}-1}+$ Selang

yakni: $\mathrm{IKn}=$ nilai indeks kesesuaian jenis kemenyan

$\mathrm{Ik}_{\mathrm{n}-1}=$ nilai indeks kesesuaian sebelumnya

$\mathrm{S}_{\min }=$ skor terendah

Selang = nilai dalam penetapan selang klasifikasi kesesuaian habitat

\section{Validasi Data}

Validasi dilakukan dengan membandingkan peta hasil kesesuaian yang dibangun menggunakan model dibandingkan dengan data observasi ditemukannya pohon kemenyan di lapangan.

Validasi $=(\mathrm{n} / \mathrm{N}) \times 100 \%$

Dimana: $\mathrm{n}=$ jumlah ditemukannya pohon kemenyan pada satu kelas kesesuaian

$\mathrm{N}=$ jumlah total pohon kemenyan hasil survey

\section{HASIL DAN PEMBAHASAN}

\section{A. Hasil}

\section{Model yang dibangun}

Penentuan peubah yang akan digunakan dalam membangun model ini didasarkan pada persyaratan tumbuh tanaman yaitu ketinggian tempat, curah hujan, jenis tanah dan kemiringan. Ketinggian tempat akan berpengaruh pada suhu rata-rata tahunan yakni semakin tinggi tempat maka suhunya akan semakin rendah juga akan berpengaruh pada tipe vegetasinya. Curah hujan akan berpengaruh pada tipe iklim suatu daerah dengan menggabungkan pada jumlah bulan basah dan bulan kering dalam satu tahun. Curah hujan ini akan mempengaruhi ketersediaan air dan kemampuan adaptasi suatu jenis tanaman akan ketersediaan air di tempat tumbuhnya dan berpengaruh juga terhadap tipe penutupan vegetasi di daerah tersebut.

\section{Kelas ketinggian}

Provinsi Sumatera Utara mempunyai kisaran ketinggian dari muka laut mulai dari 0 meter hingga lebih dari 2.400 meter. Daerah dataran rendah menyebar dari tengah ke arah Timur sedangkan ke arah Barat relatif mempunyai kemiringan yang lebih curam dan elevasi yang tinggi karena daerah ini merupakan rangkaian dari pegunungan Bukit Barisan yang memanjang dari Selatan hingga ke Utara. Walaupun demikian, penyebaran jenis-jenis tanaman tidak bersifat kontinyu mengikuti alur pegunungan tersebut dan beberapa jenis, termasuk kemenyan hanya menyebar di sekitar Sumatera Utara dan Sumatera Selatan saja, sama seperti beberapa jenis lainnya termasuk jenis Taxus sumatrana (Harahap dan Izudin, 2002).

Data kelas ketinggian didapatkan dengan menggunakan data kontur yang diolah menjadi kelas ketinggian dengan selang 300 meter. Hal ini untuk meringankan beban pengolahan datanya karena jika menggunakan kontur aslinya akan memakan waktu yang relatif lama dan ada kemungkinan gagal dalam pengolahannya. Hasil 


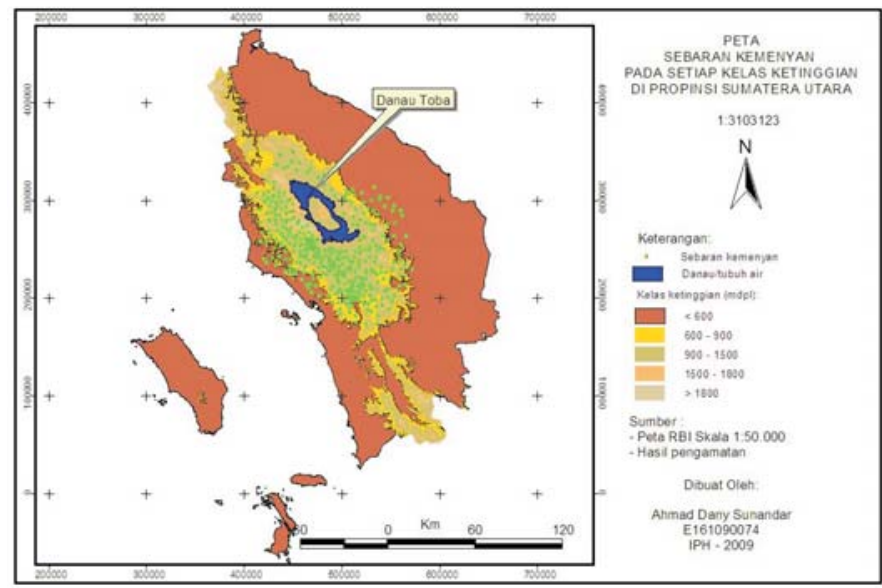

Gambar(Figure) 2. Sebaran kemenyan berdasarkan peta kelas ketinggian tempat (Pengolahan Peta RBI tahun 1989) (Styrax spreading area based on elevation map. (Analyzed form RBImap year 1989))

dari peta kelas ketinggian ini kemudian dibagi lagi menjadi lima kelas dan masing-masing kelas diberikan skor sesuai dengan preference tempat tumbuh kemenyan.

Sebaran kemenyan di setiap kelas ketinggian dapat diketahui dengan melakukan overlay menggunakan Identity pada menu XTools sehingga diketahui jumlah titik pada setiap kelas ketinggian. Overlay sebaran kemenyan pada setiap kelas ketinggian dapat dilihat pada Gambar 2.

\section{Kelas lereng/Slope}

Secara umum, daerah di sebelah barat $\mathrm{Pu}$ lau Sumatera merupakan daerah pegunungan lipatan hasil tumbukan dari lempeng benua sehingga daerah tersebut mempunyai slope yang relatif lebih tinggi dibandingkan dengan daerahdaerah di sebelah timur. Selain mempunyai slope yang relatif lebih tinggi, daerah ini juga mempunyai patahan dan merupakan daerah hasil erupsi gunung berapi sehingga banyak terdapat batuan.

Data kelas lereng didapatkan dengan menggunakan data kontur yang diolah menjadi data kelas lereng dengan beberapa tahapan, dimulai dengan membuat data TIN (Triangulated Irregular Network) yang kemudian diturunkan dengan "Derive Slope". Hasil dari penurunan kemiringan ini kemudian direklasifikasi menjadi lima kelas. Hasil dari peta kelas lereng ini kemudian dibagi lagi menjadi lima kelas dan masing-masing kelas diberikan skor sesuai dengan hasil observasi.

Sebaran kemenyan di setiap kelas lereng, dapat diketahui melalui cara overlay dengan menggunakan Identity sehingga diketahui jumlah



Gambar(Figure) 3. Penyebaran kemenyan berdasarkan peta slope (Pengolahan Peta RBI tahun 1989) (Styrax spreading area based on slope map (Analyzed from RBI map year 1989)) 
titik pada setiap kelas lereng. Overlay sebaran kemenyan pada setiap kelas ketinggian dapat dilihat pada Gambar 3 .

Daerah bagian tengah hingga ke arah barat Sumatera Utara terlihat mempunyai kelas lereng yang relatif lebih tinggi karena merupakan rangkaian pegunungan yang membentang dari arah selatan hingga ke utara. Berdasarkan Gambar 3, terlihat bahwa kemenyan lebih banyak menyebar di daerah dengan kemiringan yang lebih besar dari $8 \%$.

\section{Peta tanah dan peta curah hujan}

Peta tanah dan peta curah hujan diturunkan dari data yang ada pada peta sistem lahan (Land system) dari peta RePProT (Regional Planning Programs for Transmigration) dengan pengolahan pada data atributnya. Selanjutnya sama seperti kelas ketinggian dan kelas lereng. Penyebaran kemenyan untuk setiap jenis tanah dan kelas curah hujan juga dilakukan dengan melakukan identity.

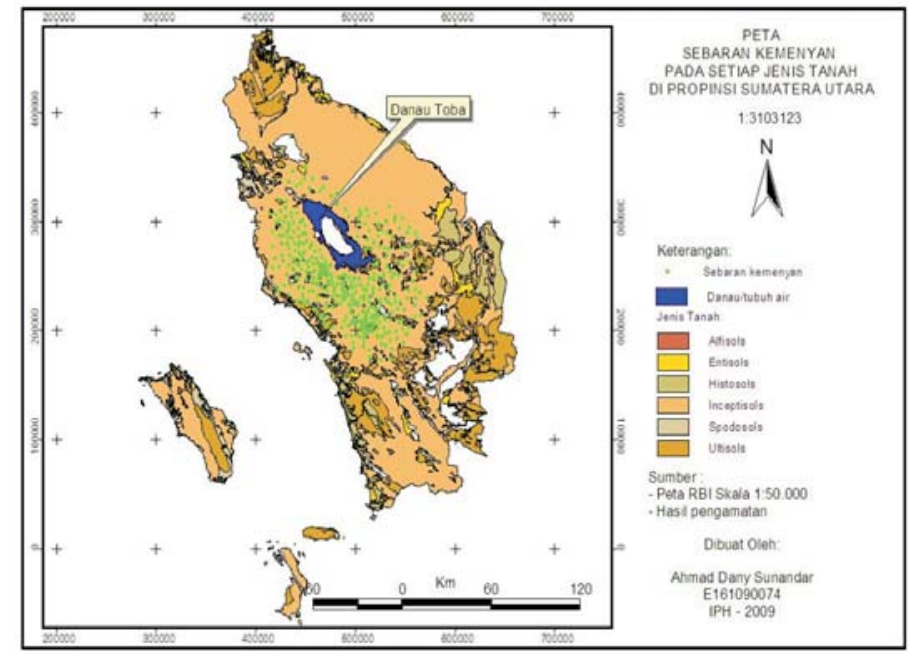

Gambar(Figure) 4. Penyebaran kemenyan berdasarkan peta jenis tanah pada RePProT (Styrax spreading area based on soil type map on RePProT)

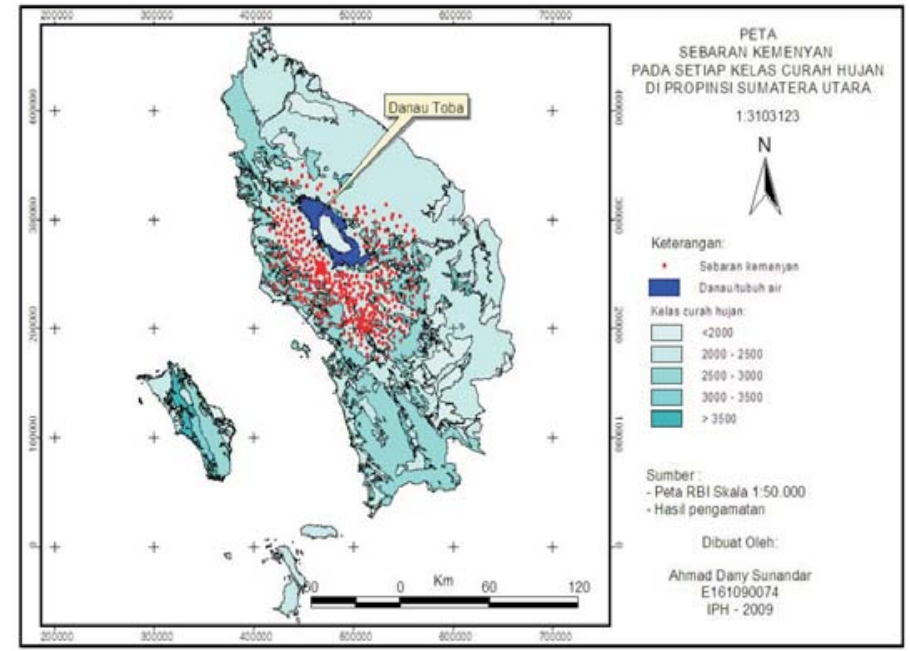

Gambar(Figure) 5. Penyebaran kemenyan berdasarkan peta kelas curah hujan pada RePProT (Styrax spreading area based on rainfall class map on RePProT) 


\section{Hasil pembobotan}

Penelitian mengenai data variabel yang dianggap mempengaruhi penyebaran jenis kemenyan secara khusus belum pernah dilakukan tetapi mengacu pada literatur yang ada, penyebaran suatu jenis sangat dipengaruhi oleh kondisi biofisiknya, antara lain tipe iklim (curah hujan, jumlah bulan basah dan bulan kering), elevasi/ketinggian tempat (berpengaruh pada suhu rata-rata tahunan), jenis tanah (berhubungan dengan tekstur, kedalaman solum dan tingkat kesuburannya) dan slope/kemiringan (berpengaruh pada kedalaman solum dan kesuburan tanahnya). Masing-masing faktor tersebut akan berinteraksi dan menjadikan suatu areal menjadi cocok atau tidak untuk suatu jenis tanaman tertentu.

Pengaruh dari masing-masing faktor tersebut dapat diketahui dengan melakukan skoring dan pembobotan. Penetapan variabel pada skoring dilakukan berdasarkan pada literatur yang ada dan hasilnya adalah sebagai berikut:

Tabel (Table) 1. Hasil skoring dan pembobotan untuk setiap faktor (Scoring and weigthing result of each factor)

\begin{tabular}{|c|l|c|c|}
\hline No & \multicolumn{1}{|c|}{ Variabel } & Skoring & Bobot \\
\hline 1 & Lereng/Slope & & \\
& $0-8 \%$ & 1 & 0,258 \\
& $8-15 \%$ & 9 & \\
& $15-25 \%$ & 7 & \\
& $25-40 \%$ & 3 & \\
& $>40 \%$ & 3 & \\
\hline 2 & Jenis Tanah & 4 & 0,270 \\
& No data & 2 & \\
& Ultisols & 1 & \\
& Entisols & 9 & \\
& Inceptisols & & \\
\hline \multirow{2}{*}{3} & Curah Hujan & 1 & \\
& $<2.000$ & 9 & \\
& $2.000-2.500$ & 6 & \\
& $2.500-3.000$ & & \\
\hline 4 & Ketinggian & 1 & \\
& $<600$ & 9 & \\
& $600-900$ & 8 & \\
& $900-1.500$ & 4 & \\
& $1.500-1.800$ & & \\
& $>1.800$ & & \\
\hline
\end{tabular}

Berdasarkan hasil skoring dan pembobotan di atas maka dapat disusun model indeks kesesuaian untuk jenis kemenyan di Sumatera Utara sebagai berikut:

$$
\begin{aligned}
\mathrm{IK}= & \left(0,258 \times \mathrm{F}_{\text {slope }}\right)+\left(0,127 \times \mathrm{F}_{\text {jenis tanah }}\right)+(0,189 \mathrm{x} \\
& \left.\mathrm{F}_{\text {curah hujan }}\right)+\left(0,427 \times \mathrm{F}_{\text {elevasi }}\right)
\end{aligned}
$$
yakni :

IK $=$ indeks kesesuaian untuk kemenyan

$\mathrm{F}_{\text {slope }} \quad=$ skor kesesuaian untuk faktor kelas lereng/slope

$\mathrm{F}_{\text {jenistanah }}=$ skor kesesuaian untuk faktor jenis tanah

$\mathrm{F}_{\text {curah hujan }}=$ skor kesesuaian untuk faktor curah hujan

$\mathrm{F}_{\text {elevasi }}=$ skor kesesuaian untuk faktor elevasi
Model di atas menghasilkan kisaran nilai antara 0 - 9,009 yang kemudian dibagi menjadi lima kelas kesesuaian dengan menggunakan metode Quantile sehingga diperoleh selang seperti pada Tabel 2.

Model ini kemudian dispasialkan dengan memberikan nilai pada masing-masing layer sesuai dengan skor dan bobot setiap peubah kemudian digabungkan sehingga menghasilkan nilai total dengan kisaran nilai seperti yang tercantum pada Tabel 2. Nilai total inilah yang kemudian menjadi dasar dalam menentukan kelas kesesuaian lahan untuk kemenyan. Peta kelas kesesuaian ini dapat dilihat pada Gambar 6 dan luas masing-masing kelas kesesuaian dapat dilihat pada Tabel 3 . 
Tabel (Tabel) 2. Selang nilai kelas kesesuaian untuk kemenyan (Range value of styrax suitability class)

\begin{tabular}{|c|c|c|}
\hline No & Kisaran Nilai & Kesesuaian \\
\hline 1 & $0-3,156$ & Tidak sesuai \\
\hline 2 & $3,156-4,297$ & Kurang sesuai \\
\hline 3 & $4,297-5,364$ & Agak sesuai \\
\hline 4 & $5,364-6,862$ & Sesuai \\
\hline 5 & $6,862-9,009$ & Sangat Sesuai \\
\hline
\end{tabular}

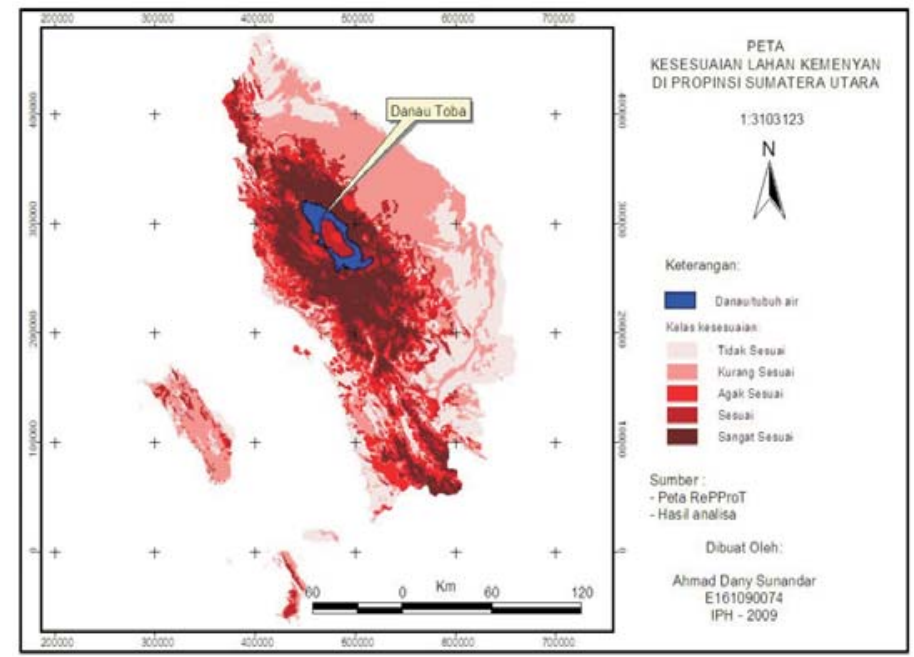

Gambar(Figure) 6. Peta kelas kesesuaian untuk jenis kemenyan di Sumatera Utara (Land suitability map of styrax in North Sumatra)

Tabel (Table) 3. Luas setiap kelas keseuaian (Wide area for each suitability class)

\begin{tabular}{|c|c|c|c|}
\hline No & Kelas Kesesuaian & Luas (Ha) & Persentase \\
\hline 1 & Tidak Sesuai & 1.716 .344 & 23,78 \\
\hline 2 & Kurang Sesuai & 2.411 .789 & 33,41 \\
\hline 3 & Agak Sesuai & 898.676 & 12,45 \\
\hline 4 & Sesuai & 865.273 & 11,99 \\
\hline 5 & Sangat Sesuai & 1.326 .658 & 18,38 \\
\hline & Tot a 1 & 7.218 .740 & \\
\hline
\end{tabular}

\section{Validasi}

Validasi merupakan langkah akhir dalam pemodelan dan ditujukan untuk mengetahui tingkat kepercayaan terhadap model yang dibangun. Data yang digunakan adalah data hasil obervasi yang diambil bersamaan dengan data yang digu-nakan dalam pembuatan model. Jumlah unit contoh (dalam hal ini point) yang digunakan untuk validasi model adalah sebanyak 100 titik pengamatan.

Hasil validasi kelas kesesuaian untuk jenis kemenyan di Sumatera Utara adalah seperti yang tertera pada Tabel 4.

Berdasarkan Tabel 4, hasil uji validasi ternyata model yang dibangun mempunyai tingkat akurasi dalam memprediksi kesesuaian lahan untuk jenis kemenyan yang cukup tinggi yaitu $85,28 \%$ (yang tercetak tebal). Hal ini ditunjukkan dari lebih banyaknya kemenyan yang dapat ditemui di areal yang memang mempunyai kelas kesesuaian yang tinggi. Overlay peta kesesuaian yang sudah dibangun dengan peta sebaran untuk validasi dapat dilihat pada Gambar 7. 
Tabel (Table) 4. Validasi model kesesuaian untuk jenis kemenyan (Model validation result)

\begin{tabular}{|c|l|c|c|c|}
\hline No & \multicolumn{1}{|c|}{ Kesesuaian } & Jumlah Titik & Jumlah Pohon & Validasi \\
\hline 1 & Tidak Sesuai & 1 & 16 & 1,44 \\
\hline 2 & Kurang Sesuai & 6 & 48 & 4,31 \\
\hline 3 & Agak Sesuai & 10 & 100 & 8,98 \\
\hline 4 & Sesuai & 14 & 135 & $\mathbf{1 2 , 1 2}$ \\
\hline 5 & Sangat Sesuai & 69 & 815 & $\mathbf{7 3 , 1 6}$ \\
\hline & Tot a l & 100 & 1.114 & 100,00 \\
\hline
\end{tabular}

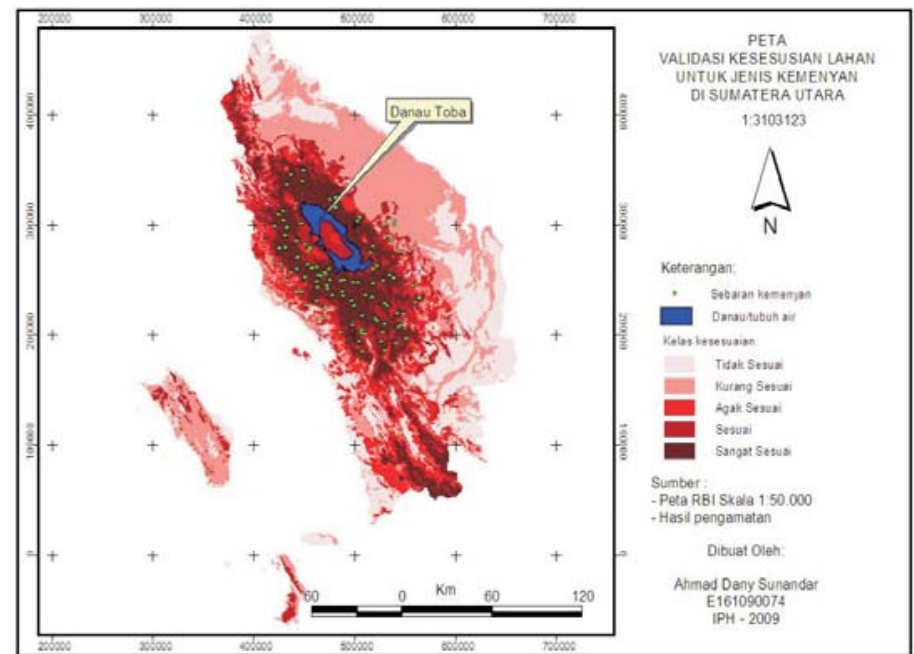

Gambar(Figure) 7. Peta validasi kesesuaian lahan untuk kemenyan (Validation map of land suitability of styrax)

\section{B. Pembahasan}

Jenis tanah berpengaruh terhadap tingkat kesuburan, kedalaman solum, kemasaman dan erodibilitasnya. Untuk di bagian barat Sumatera Utara, tanah yang terbentuk umumnya berasal dari pelapukan batuan hasil letusan gunung berapi Toba dari jenis batuan tuff sehingga menghasilkan tanah yang relatif masam. Berdasarkan pengolahan data RePProT, jenisjenis tanah yang ada di Sumatera Utara khususnya di tempat tumbuh kemenyan pada umumnya jenis Inceptisol (dystropepts dan dystrandepts), Ultisols (tropudults, paleudults) dan Entisols (fluvaquents, hydraquents) yang secara umum termasuk pada tanah-tanah mineral yang kurang subur dan mempunyai $\mathrm{pH}$ yang relatif rendah (Nursanti dan Rohim, 2010).

Kemenyan tumbuh baik pada solum tanah yang dalam, dengan $\mathrm{pH}$ tanah antara 4 - 7 dengan curah hujan yang cukup tinggi dan tersebar merata dengan tipe iklim $\mathrm{A}$ dan $\mathrm{B}$ menurut klasifikasi Schmidt dan Ferguson. Tanaman ini tidak memerlukan persyaratan yang istimewa terhadap jenis tanah dan dapat tumbuh pada tanah Podsolik, Andosol, Latosol, Regosol dan berbagai asosiasinya, mulai dari tanah berstruktur berat sampai ringan serta pada tanah yang subur sampai kurang subur. Jenis tanaman ini tidak tahan terhadap genangan, sehingga untuk pertumbuhannya memerlukan tanah yang porositasnya tinggi (mudah meneruskan/meresapkan air) (Heyne, 1987).

Berdasarkan model yang dibangun, bagian barat Sumatera Utara merupakan daerah pegunungan dan mempunyai elevasi yang relatif lebih tinggi dari daerah di sebelah timur. Menurut Pinyopusarerk (1994) dalam Jayusman et al., (1999), tempat tumbuh pohon kemenyan cukup bervariasi yaitu dari dataran rendah sampai dataran tinggi yaitu pada ketinggian tempat 60 - $2.100 \mathrm{dpl}$. Sebagian besar kemenyan menyebar pada daerah yang mempunyai 
ketinggian lebih dari 600 meter dpl (Gambar 2). Hal ini menunjukkan bahwa kemenyan mempunyai preferensi untuk dapat berkembang lebih baik pada ketinggian tersebut. Hal ini juga sejalan dengan pendapat FAO (2001) yang menyebutkan bahwa kemenyan tumbuh lebih baik dan mempunyai produktivitas getah yang lebih tinggi pada daerah dataran tinggi. Faktor ketinggian ini juga yang mempunyai nilai hasil skoring yang paling tinggi diaantara keempat faktor yang digunakan dalam skoring.

Sebagian besar Sumatera Utara mempunyai jenis tanahnya Inceptisols (berdasarkan klasifikasi USDA) dimana sebagian besar pohon kemenyan hidup pada jenis tanah ini. Meskipun jenis tanah ini merupakan tanah mineral yang kurang subur tetapi di lapangan, sebagian besar pohon kemenyan hidup di dalam tegakan yang kaya akan bahan organik dari pelapukan serasah dan bahan-bahan organik lainnya sehingga mempunyai hara yang relatif tinggi. Hasil pengolahan peta sistem lahan juga menghasilkan peta kelas curah hujan seperti pada Gambar 5 dimana terlihat bahwa sebagian besar Sumatera Utara mempunyai curah hujan antara 2.000 $3.000 \mathrm{~mm} /$ tahun. Penyebaran kemenyan juga terlihat lebih banyak pada kisaran kelas curah hujan ini. Hal ini sangat mendukung dalam penyebaran kemenyan karena jika daerah tersebut mempunyai curah hujan yang terlalu tinggi akan menyebabkan kemenyan mudah gugur bunganya sehingga menjadi sulit untuk berkembang.

Hasil pembobotan terlihat bahwa faktor ketinggian tempat mempunyai pengaruh yang paling besar terhadap penyebaran kemenyan disusul faktor slope. Hal ini didukung oleh beberapa penelitian bahwa memang kemenyan lebih banyak ditemukan di daerah yang mempunyai ketinggian lebih dari 900 meter dpl dan dalam FAO (2001) menyebutkan bahwa walaupun kemenyan dapat tumbuh di dataran rendah tapi lebih banyak ditemui di dataran tinggi dan mempunyai produktivitas getah yang lebih tinggi pula. Sedangkan bobot untuk jenis tanah mempunyai nilai yang paling rendah karena pada peta jenis tanah yang digunakan (dengan skala 1:250.000), hasil pengolahan peta land system menunjukkan bahwa jenis tanah di wilayah kajian didominasi oleh Inceptisols dimana sebagian besar kemenyan menyebar pada tanah jenis ini sehingga hasil pembobotan memberikan nilai yang paling rendah.
Hasil skoring menunjukkan tinggi rendahnya kemunculan pohon kemenyan pada salah satu peubah. Hasil overlay antara data observasi dengan keempat layer menunjukkan bahwa kemunculan pohon kemenyan tidak terdapat pada setiap peubah yang ada pada masingmasing layer. Contohnya pada layer jenis tanah dapat ditemui pohon kemenyan karena memang proporsi jenis tanah tersebut yang relatif kecil atau memang kemunculan pohon kemenyan yang terbatas pada jenis tanah tertentu saja. Demikian juga dengan curah hujan dimana dari lima kelas curah hujan, hanya tiga kelas yang dapat ditemukan pohon kemenyan.

Berdasarkan model yang dibangun dan hasil validasi menunjukkan bahwa model yang dibangun mempu menjelaskan $85,28 \%$ data untuk areal yang sesuai untuk jenis kemenyan. Model kesesuaian ini terbatas pada kesesuaian tempat tumbuh dimana tanaman kemenyan ditemukan dengan sifat biofisik lingkungannya, belum pada tahap kesesuaian dengan produktivitas getahnya karena memang belum pernah dilakukan penelitian mengenai hal tersebut.

\section{KESIMPULAN}

1. Faktor-faktor biofisik yang mempengaruhi pertumbuhan kemenyan adalah ketinggian tempat, lereng, jenis tanah dan curah hujan. Kemenyan dapat tumbuh pada kisaran ketinggian yang luas namun lebih banyak tumbuh pada ketinggian lebih dari 900 meter dpl. Ketinggian (elevasi) ini merupakan faktor yang paling berpengaruh dalam penyusunan peta kesesuaian lahan jenis kemenyan. Model yang diperoleh adalah sebagai berikut: $\mathrm{IK}=$ $\left(0,258 \times \mathrm{F}_{\text {slope }}\right)+\left(0,127 \times \mathrm{F}_{\text {jenis tanah }}\right)+(0,189 \mathrm{x}$ $\left.\mathrm{F}_{\text {curah hujan }}\right)+\left(0,427 \times \mathrm{F}_{\text {elevasi }}\right)$.

2. Hasil analisa spasial memperlihatkan bahwa areal yang mempunyai tingkat kesesuaian yang tinggi menyebar di sekitar Danau Toba dan meliputi areal seluas 2.191.931 hektar atau $30,37 \%$ dari total luas wilayah Propinsi Sumatera Utara. Areal ini didominasi oleh areal yang mempunyai ketinggian antara 600 - 1.800 meter dpl dengan slope antara $8-15 \%$.

3. Hasil validasi terhadap model spasial yang dibangun mempunyai nilai $85,28 \%$ yang berarti bahwa model tersebut dapat menerangkan $85 \%$ dari data yang ada dan dapat dikatakan sebagai model yang valid. 


\section{DAFTAR PUSTAKA}

Anonymous. 2006. Kemenyan Tapanuli Utara: Komoditi Andalan yang Kurang Diminati. Majalah Kehutanan Indonesia, Edisi IV. Jakarta.

FAO. 2001. Monograph of Benzoin (Balsamic Resin from Styrax Species). (Editor: Masakazu K. and V. J. Dennis) Food and Agriculture Organization of the United Nations Regional Office for Asia and the Pacific Bangkok, Thailand

Guntara, I. 2007. Tahun Ini, Disbun Sumut Targetkan Produksi Kemenyan 6.425 Ton. Medan Bisnis tanggal 23 Mei 2007.

Harahap, R.M.S. dan E. Izudin. 2002. Konifer di Sumatera Bagian Utara. Konifera No. 1 thn XVII Desember 2002. Balai Penelitian Kehutanan Pematang Siantar. Parapat.

Heyne, K. 1987. Styraceae. Tumbuhan Berguna Indonesia Jilid III. Badan Penelitian dan Pengembangan Kehutanan. Jakarta. Hal $1601-1609$.

Jayusman. 1998. Silvikultur Tanaman Kemenyan (Styrax sp). Prosiding Ekspose Hasil-Hasil Penelitian Balai Penelitian Kehutanan Pematang Siantar. Pematang Siantar, 25 Maret 1998. hal 32-38.

Jayusman, R.A. Pasaribu, dan S. Walpen. 1999. Pedoman Teknis Budidaya Kemenyan (Styrax spp.). Konifera Visi dan Informasi Teknis BPK Pematang Siantar Vol. 2 No. 1.
Kalogiroua, S. 2002. Expert System and GIS: An Application of Land Suitability Evaluation Computers. Environment and Urban Systems 26: 89 - 112.

Liu, Y. S. and X. Z. Deng. 2001. Structural Pattern of Land Types and Optimal Allocation of Land Use in Qinling Mountainous. Journal of Geographical Science 11(1): 99 - 109.

Liu, Y. S., J.Y. Wang., and L.Y. Guo. 2006. GISBased Assessment of Land Suitability for Optimal Allocation in the Qinling Mountains, China. Pedosphere 16(5): 579 $-586$.

Malczewski, J. 2004. GIS-Based Land-Use Suitability Analysis: A Critical Overview. Progress in Planning 62: 3 - 65.

Mendoza, G.A. and R., Prabhu. 2002. Multidimensional Measurements and Approaches to Forest Sustainability Assessments, Edited by Pukkala, T. Multiobjective Forest Planning. Kluwer Academic Publishers. Dordrecht.

Nursanti, I. dan A.M. Rohim, A.M. 2010. Pengelolaan Kesuburan Tanah Mineral Masam untuk Pertanian. Diakses tanggal 2 Mei 2010. http://blog.unila. ac.id.

Warintek. 2009. Styrax benzoin DRYAND. http:/www.warintek.ristek.go.id/. Diakses tanggal 9 Nopember 2009. 